\begin{tabular}{|c|c|c|}
\hline Beitr. Ent. & Keltern & ISSN 0005-805X \\
\hline $\mathbf{5 9}(2009) 1$ & S. $239-246$ & 15.07 .2009 \\
\hline
\end{tabular}

\title{
Floromadane, a new genus of baridine weevils associated with Rubiaceae in Costa Rica and Panama
}

\section{(Coleoptera: Curculionidae: Baridinae)}

With 15 figures

JENS PRENA

\section{Summary}

Floromadane gen. $\mathrm{n}$. is described and includes three new species from Costa Rica and Panama; F. atrorubens sp. n. (type species), F. pictulus sp. n., and F. tumens sp. n. It is considered most closely related to Pardisomus PASCOE in the tribe Optatini. Adults and larvae are associated with Psychotria and possibly other Rubiaceae.

\section{Zusammenfassung}

Floromadane gen. n. wird beschrieben und enthält drei neue Arten aus Costa Rica und Panama: F. atrorubens sp. n. (Typusart), F. pictulus sp. n. und F. tumens sp. n. Als engster Verwandter wird Pardisomus Pascoe in den Optatini angesehen. Käfer und Larve sind an Psychotria und möglicherweise andere Rubiaceae gebunden.

Key words

Weevils, new genus, new species, Rubiaceae, Central America

New species

F. atrorubens sp. n., F. pictulus sp. n., F. tumens sp. n.

\section{Introduction}

In a previous study (Prena 2003), I synonymized four genera with Pardisomus Pascoe using a combination of morphological and ecological criteria as exemplary evidence for the existence of artificial barriers imposed by the current concepts of the tribes Ambatini, Peridinetini, Pantotelini, Cyrionychini, and Optatini of the subfamily Baridinae. The recognition of Pentagonia (Rubiaceae) as the relevant host plant genus for Pardisomus, combined with subsequent surveying of the Costa Rican flora, provided the necessary material and data in that particular case. When extending the scope of the study of Rubiaceae-feeding weevils to other plant genera, I recently discovered some other species with potential relevance for a future reclassification of these weevils. One group of them is represented reasonably well in collections and is described herein.

This study was conducted in collaboration with the Instituto Nacional de Biodiversidad (INBio), the Ministerio del Ambiente y Energia, and the Organization for Tropical Studies (OTS). Travel to Costa Rica and field work were supported by grants of the National Science Foundation (DEB-0072702), the National Geographic Society (7331-02, 7751-04), and the German Science Foundation (444 COS-112/1/04) as part of the Arthropods of La Selva project (http:// viceroy.eeb.uconn.edu/ALAS/ALAS.html). Thanks are due to Jack Longino (Evergreen State 
College) for excellent project management, Alvaro Herrera (INBio) for administrative support, José Gonzales (OTS) and Barry Hammel (Missouri Botanical Garden) for identification of Psychotria chitaria, and all project members for assistance and company in the field. RoBerT Hamilton (Loyola University, Chicago), Robert Anderson (Canadian Museum, Ottawa), Ronald Ochoa, and Allen Norrbom (both USDA-ARS-SEL, Washington, DC) commented on the manuscript and made helpful suggestions.

\section{Material and methods}

Champion's (1907) concept of Optatini is adopted here without further discussion; the phylogenetic relationships in this tribe are currently being investigated by M. BARBOSA (Brazil). Twenty-two specimens were studied from the following collections (curators in brackets): CMNC, Canadian Museum of Nature, Ottawa (R. Anderson, F. Génier); CWOB, Charles W. O’Brien personal collection, Green Valley, AZ; HPSC, Henry P. Stockwell personal collection, Smithsonian Tropical Research Institute, Panama; INBC, Instituto Nacional de Biodiversidad, Costa Rica (A. Solís); JPPC, Jens Prena personal collection; USNM, National Museum of Natural History, Washington, DC (S. Lingafelter). Measurements of length were taken with an ocular micrometer in a dissecting microscope as follows: total length, from anterior margin of eye to abdominal apex in dorsal view; standard length, from anterior margin of pronotum to abdominal apex in dorsal view; width, greatest width at humeri. Genitalia and associated structures are illustrated only for the type species, because their morphology is of little diagnostic value for species identification. Drawings were drafted from extended focus images taken with a JVC digital camera KY-F70 and Archimed software (Microvision Instruments). Overview images of genitalia were taken with a Wild M400 photomacroscope using bottom illumination and $25 \times$ magnification. Structural details were photographed with an Olympus BX50 compound microscope. Chlorazol black was applied to highlight membranous structures.

\section{Floromadane PrenA, gen. n.}

\section{Recognition:}

Species of Floromadane concur with CHAMPION's (1907) concept of Optatini in being broadly triangular, having dentate femora and the pygidium covered by the elytral apices. The included species can be distinguished from those of related genera by the following character states: (1) antennal club moderately elongate, neither short oval as in Pardisomus nor very elongate and spindleshaped as in Telemus PAscoe and Macroptatus ChAmpion, (2) proxocae contiguous, (3) prosternal channel obsolete, (4) ventral tooth of profemur reduced, (5) rostrum moderately thick, round in cross-section, (6) elytral interstriae costate at least on apical half, 2 and 3 raised near middle, (7) sclerolepidia of type $2 \mathrm{a}$ or possibly reduced type 3 according to classification of LyaL et al. (2006), often partially or entirely absent, (8) all life stages associated with plants in the Rubiaceae.

\section{Description:}

Size: Total length 3.7-6.5 mm, standard length 3.6-6.1 mm, width 1.8-3.7 mm. Color: Integument reddish to dark brown, scales yellowish to white forming color pattern or not (Fig. 1-6). Head: Frontal fovea present, eyes separated by width of rostrum at base, rostrum rather slender, subcylindrical, scrobes lateral and slightly descending, antenna inserted near midlength, scape slender and clavate, funicle 7-segmented, club oval and pubescent, mandibles little protruding and curved, with two teeth of equal size. Prothorax: Pronotum bell-shaped, anterior portion tubular and moderately projected over frons, disk gently to strongly arched; prosternal channel obsolete, 
frontal portion emarginated, fore coxae contiguous. Scutellum: Flat, as long as wide, anterior margin slightly sloping, apex convex, flushing with elytral margins. Elytra: Shape subtriangular, in profile slightly arching with basal third depressed, humeri prominent and much wider than pronotum, elytral apices conjointly rounded, subapical callus moderate, striae narrow, deep, and continuous, interstriae costate at least on apical half, 2 and 3 raised and costate near middle. Legs: Length subequal, meso- and metafemora 1-dentate ventrally, profemoral tooth more or less reduced, claws small, subconnate or separate at base. Sclerolepidia: Digitate, split in two lobes (type 2a or possibly reduced type 3 according Lyal et al. 2006). Stridulatory organs: 0-2 pairs of sclerotized plectra near base of tergite 7. Male genitalia and associated structures (Fig. 7-13): Aedeagus as in Fig. 7-9, apodemes slender, approximately $2.5 \times$ longer than body of aedeagus, internal sac long, ejaculatory duct modified to sclerotized flagellum, base of flagellum abruptly curved, with basal appendage attached to internal sac, duct inserted at distal base of flagellum

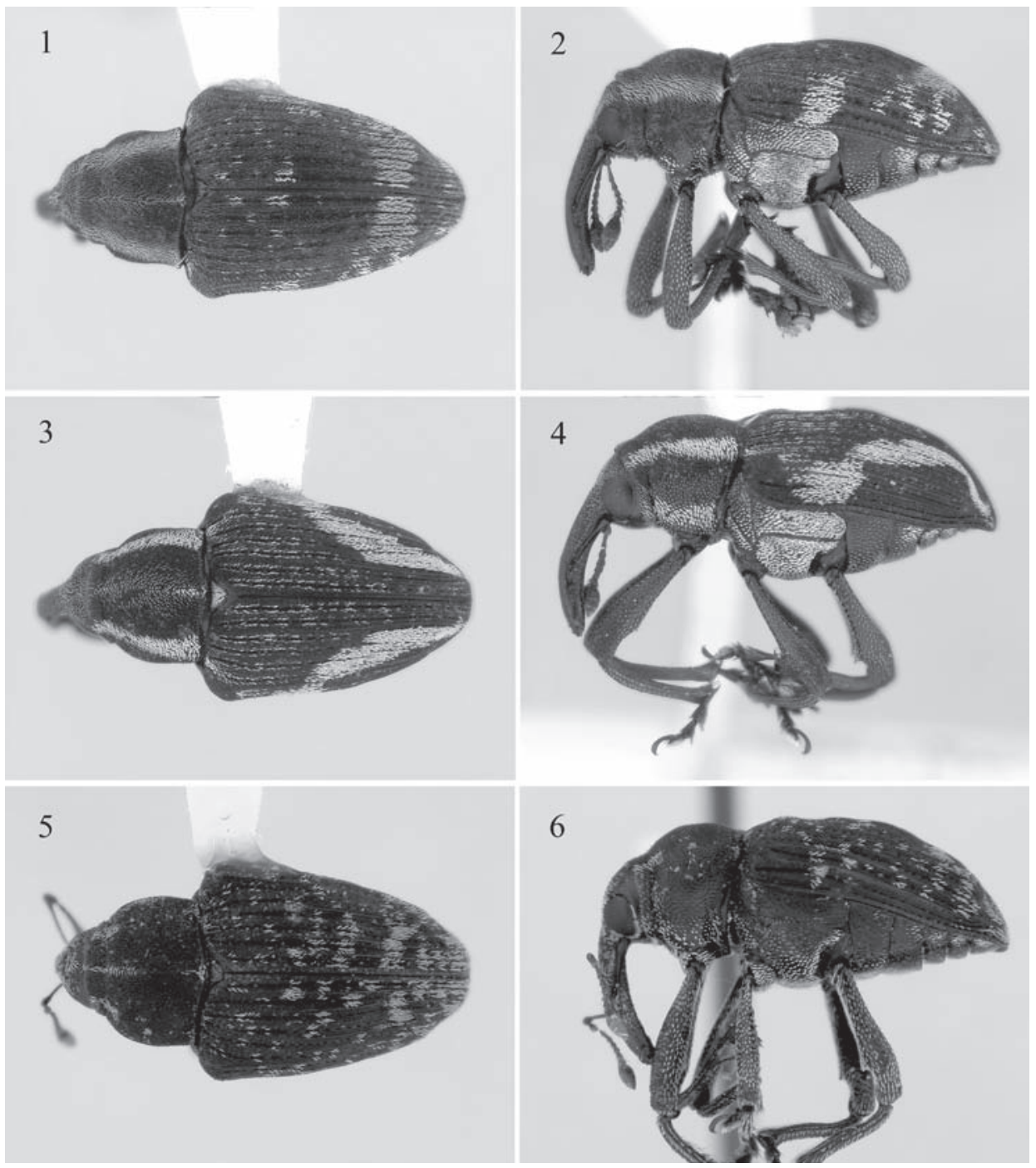

Fig. 1-6: Floromadane, habitus, dorsal and lateral views. 1-2. F. atrorubens; 3-4. F. pictulus; 5-6. F. tumens. 

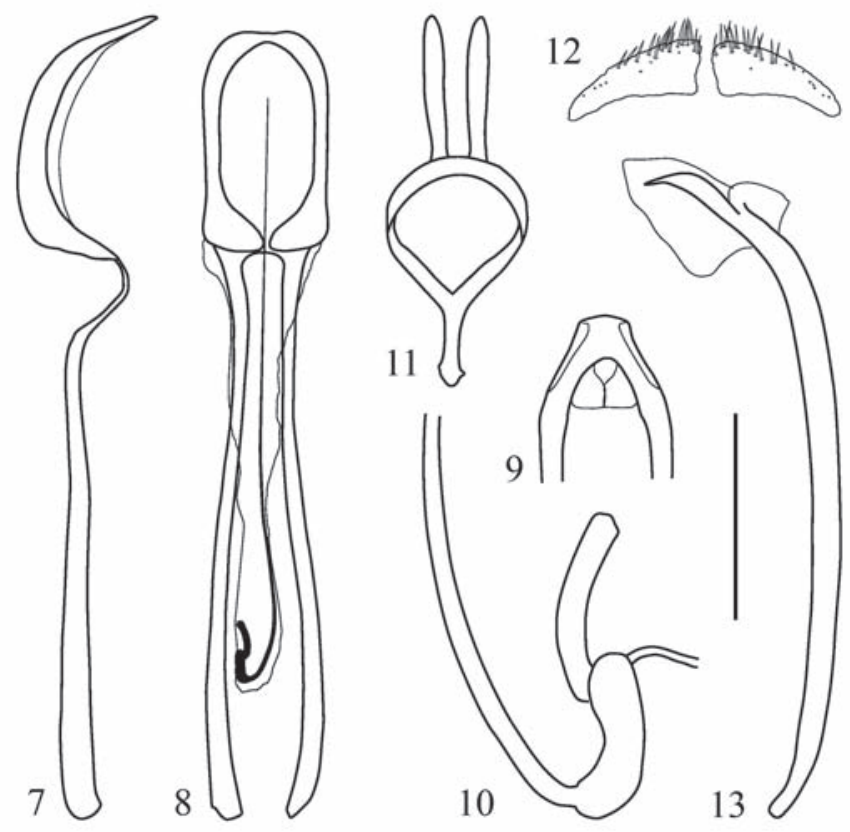

Fig. 7-13: Floromadane atrorubens, male genitalia and associated structures. 7-8. aedeagus, lateral and dorsal views; 9. apex of aedeagus, dorsal view; 10. base of flagellum; 11. tegmen; 12. sternite $8 ; 13$. sternite 9. Scale bar $0.1 \mathrm{~mm}$ for Fig. 10 and $0.5 \mathrm{~mm}$ for all other figures.
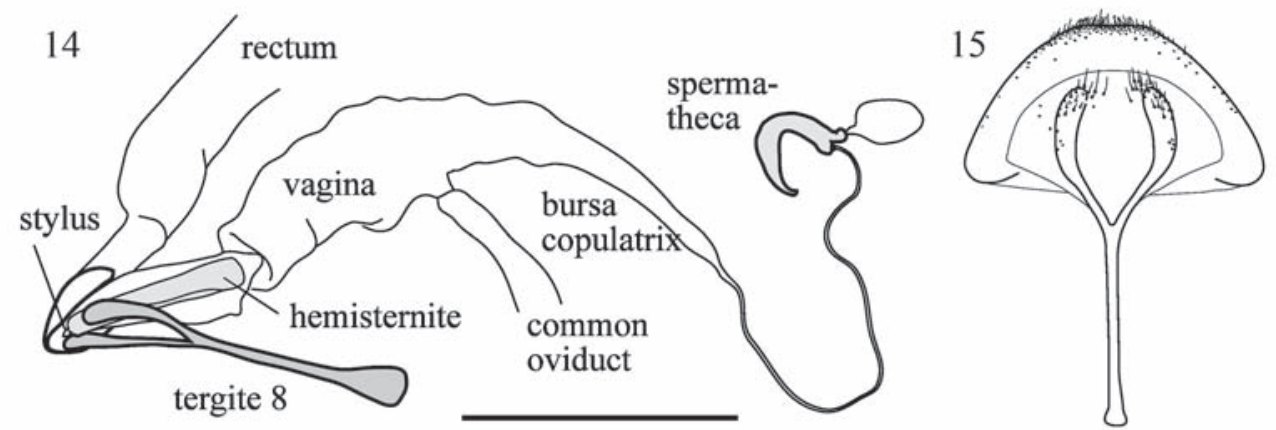

Fig. 14-15: Floromadane atrorubens, female genitalia and associated structures. 14. genital tract, lateral view; 15. sternite 8 and tergite 8 , ventral view. Scale bar $1 \mathrm{~mm}$.

(Fig. 10); tegmen as in Fig. 11; sternite 8 membranous, medially unpigmented (Fig. 12); sternite 9 curved subdistally, lateral arm rudimentary (Fig. 13). Female genitalia and associated structures (Fig. 14-15): Sternite 8 symmetric, distally forked into weakly sclerotized arms and embedded in unpigmented membrane; hemisternite pigmented, stylus with numerous (20+) distal setae and sensilla; bursa conspicuously tapered; spermatheca sclerotized, cornu slender, U-shaped, tapered distally, ramus subterminal, shape and size variable, nodulus inconspicuous; spermathecal duct unpigmented, approximately as long as sternite 8 , inserted distally in bursa.

\section{Distribution:}

The three currently recognized species occur on the Atlantic side of Costa Rica and in Panama, Central America. 


\section{Etymology:}

The name of the new genus is an acronym derived from the forenames of our able field assistants in the AlaS project: Flor Cascante, Ronald Vargas, Maylin Paniagua, Danilo Brenes, and Nelci Oconitrillo. The gender is masculine.

\section{Type species:}

Floromadane atrorubens PRENA.

\section{Discussion:}

Floromadane belongs to a lineage of Neotropical Baridinae with covered pygidium, ventrally dentate femora, and at least partially scaled integument. Their current classification contains outdated views of SchönherR $(1833,1845)$ who assigned the genera to Divisio I, Erirhinides and Divisio II, Cryptorhynchides and Baridides of Legio II, Mecorhynchi. LaCORDAIRE $(1863,1866)$ adopted this scheme and added new family-group names to it. CHAmpion (1907) was the first to recognize their close relationship and, by grouping them together, defined the Baridinae in today's sense. Since CASEY's (1922) description of the Cyrionychini, a total of five tribes have been used rather inconsistently for the above mentioned complex of weevils, i.e., Ambatini Lacordaire, Cyrionychini Casey [regarded as a subtribe of the Pantotelini by Hustache (1938)], Optatini Champion, Pantotelini Lacordaire, and Peridinetini Lacordaire [included in the Ambatini by CASEY (1922)].

Floromadane, Pardisomus, and at least one undescribed genus include species associated with Rubiaceae. Most species of the other genera of the above complex appear to be associated with different plant families, particularly with Piperaceae and Annonaceae, except for a few species in the Cyrionychini, where CASEY (1922) lumped most small-sized species of CHAMpion's Optatini. Besides the association with Rubiaceae, I presently do not recognize any derived character that is shared only by Floromadane and Pardisomus. As a preliminary solution, I place Floromadane in the Optatini and hypothesize a close relationship with Pardisomus. More work on the Cyrionychini is necessary before the natural relationships of these weevils can be investigated.

\section{Key to species of Floromadane}

1 Tarsal claws slender and separate at base; ventral tooth of middle femur slightly smaller than tooth of hind femur; scutellum with moderately dense vestiture of yellow scales; elytron with fascia of yellow scales arching from metasternal flank to elytral apex (may be fragmented); 300-820 m elevation. F. pictulus

1' Tarsal claws widened and subconnate at base; ventral tooth of middle femur noticeably larger than tooth of hind femur; scutellum with vestiture indistinct; elytron with subapical fascia of yellow scales not reaching metasternal flank, or without fascia; 600-2100 m elevation.

2 Integument reddish brown, tarsi fuscous; metasternal flank with conspicuous white scales; pronotum slightly arched in lateral view (Fig. 2); elytral interstria 8 with subtle median ridge; Costa Rica and western Panama. F. atrorubens

2' Integument (including tarsi) dark brown; metasternal flank without conspicuous white scales; pronotum noticeably gibbous (Fig. 6); elytral interstria 8 with distinct median ridge; central Panama. F. tumens 


\section{Floromadane atrorubens PrENA, sp. n.}

Holotype male, dissected, Costa Rica, labeled: "Estación La Casona, R.B. Monteverde,/ Prov. Punta[renas], COSTA RICA. 1500m. Jun/ 1991. N. Obando,/ L N 253250_449700 \#1714”, CRI001 694105 (INBC), "HOLOTYPE/ Floromadanel atrorubens/ Prena, 2009”.

Paratypes: 9 males, 5 females. COSTA RICA: Alajuela Prov., Tilarán, Est. San Gerardo, Senderos Tabacón y Congo, L N 317991 384374, 600 m, 14.-15.11.1998, M.A. Zumbado, manual, \#59038, INB0003306259, male (INBC); Cartago Prov., P.N. Tapantí, Quebr[ada] Segunda, $1200 \mathrm{~m}, 9^{\circ} 48^{\prime} \mathrm{N} 83^{\circ}$ 47' W, 3.-5.4.2004, J. Prena, 1 male, 2 females (JPPC); Heredia Prov., 6 km

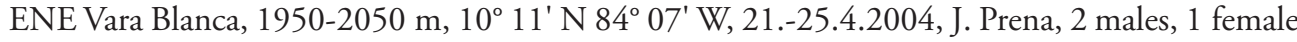
(JPPC); Puntarenas Prov., Est. Pittier, 1670 m, 11.-16.6.1995, B. Gamboa, CRI002 250168, male (INBC); Puntarenas Prov., Monteverde, 26.5.-3.6.1984, E. Riley, D. Rider, D. LeDoux, male (CWOB); San José Prov., Zurquí de Moravia, 1600 m, malaise trap, VI/1995, P. Hanson, male (CWOB). PANAMA: Chiriquí Prov., N Santa Clara, 8 51' N 82 46' W, 31.5.1977, [H. P.] Stockwell, male (HPSC); Chiriquí Prov., Hartmann’s finca, St. Clara, \pm 5000 ft. [1525 m], 15.18.6.1985, [E.] Riley, [D.] Rider, male (CWOB); Chiriquí Prov., 6 km NE Boquete, $1650 \mathrm{~m}$, 14.-19.6.1996, J. Ashe, R. Brooks, F.I.T. \#180, female (CMNC); Chiriquí Prov., $12 \mathrm{~km} \mathrm{NE}$ Santa Clara, Cerro Pando, 8 54.74' N 82 43.29' W, 1875 m, 17.-18.6.1996, R. Brooks, F.I.T. \#185, female (CMNC).

\section{Description:}

Total length 4.7-6.3 mm, standard length 4.4-6.1 mm, width 2.4-3.2 mm; integument reddish brown, tarsi fuscous, yellow scales condensed in dorsolateral pronotal vitta and in variously developed subapical elytral fascia; white scales condensed in lateral fascia between metasternum and outer interstriae (Fig. 1-2), specimens from low elevations with color pattern reduced; pronotal disk slightly arched, punctures confluent, intervals granular, confluent in midline; scutellum square, apex round to acuminate; elytra subtriangular, conjointly rounded and completely covering pygidium, interstriae costate except for flat portions of disk; ventral tooth variously reduced on profemur, largest on mesofemur; tibiae with praemucro indistinct, male with sparse fringe of long hairs on ventral edge of protibia; claws subconnate at base; male genitalia and associated structures as in Fig. 7-13, flagellum approximately $3 \times$ longer than body of aedeagus, basal portion recurved and with subdistal sclerite (Fig. 10), internal sac with slight microsculpture but without denticles.

\section{Plant association:}

I collected six adult weevils from young (sterile) specimens of two unidentified plant species possibly belonging to Psychotria. The larva makes galleries in the apical portion of the main stem, thereby inhibiting further terminal growth.

\section{Distribution:}

The species is known from six localities in premontane and montane habitats $(600-2100 \mathrm{~m})$ in Costa Rica and Panama.

\section{Epithet:}

A Latin present participle composed of ater (black or dark) and rubens (turning red). 


\section{Floromadane pictulus Prena, sp. n.}

Holotype female, Costa Rica, labeled: "COSTA RICA: Prov. Heredia:/ $10 \mathrm{~km}$ SE La Virgen, 450-/ 550m, $10^{\circ} 20^{\prime} \mathrm{N} 84^{\circ} 05^{\prime} \mathrm{W} / 14 .-20.4 .2003 /$ INBio-OET-ALAS transect”, "handcollecting/ leg. Jens Prena", "from Psychotrial chitariana", INB0003230207 (INBC), "HOLOTYPE/ Floromadanel pictulus/ Prena, 2009”.

Paratypes: 1 male, 2 females. COSTA RICA: Heredia Prov., $10 \mathrm{~km}$ SE La Virgen, 450-550 m, 10 20' $0^{\circ} 84^{\circ} 05^{\prime} \mathrm{W}, 14-20.4 .2003$, from Psychotria chitariana, J. Prena, INB0003230208, female (JPPC). PANAMA: Colon Prov., Santa Rita Ridge, 300 m, 10.11.6.1977, H. \& A. Howden, female (CMNC); Panamá Prov., Cerro Campana, 820 m, 8 40' N $79^{\circ}$ 56' W, 11.6.1995, H. Stockwell, male (HPSC).

\section{Description:}

Total length 3.7-5.1 mm, standard length 3.6-4.8 mm, width 1.8-2.7 mm; integument brown, appendages reddish brown, yellow scales condensed in dorsolateral pronotal vitta and in variously developed fascia arching from metasternum across elytral callosity to apex (Fig. 3-4), fragmented in Panamanian specimens; pronotal disk slightly arched, punctures confluent, intervals granular, confluent in midline; scutellum square, apex round to acuminate; elytra subtriangular, conjointly rounded and completely covering pygidium, interstriae costate except for flat portions of disk; ventral tooth variously reduced on profemur, largest on mesofemur; pro- and mesotibiae with praemucro distinct, male with sparse fringe of long hairs on ventral edge of protibia; claws separate at base; male genitalia similar to those of $F$. atrorubens, apex of aedeagus with sides less converging, basal portion of flagellum more narrowly curved, internal sac denticulate.

\section{Plant association:}

I collected the holotype and one paratype from foliage of Psychotria chitariana DwYER \& HAMMEL (identification confirmed by B. HammeL).

\section{Distribution:}

The species has been collected at three localities, one in Costa Rica (Atlantic side) and two in Panama, between 300-820 m elevation.

\section{Epithet:}

A modified perfect participle derived from Latin pingo, meaning fairly colored.

\section{Note:}

The specimens from the three collecting sites show considerable variation in the color pattern; only the two Costa Rican specimens possess completely developed fasciae. Because the only male in the series is atypically small, I selected a fully developed female as holotype.

\section{Floromadane tumens Prena, sp. n.}

Holotype male, dissected, Costa Rica, labeled: "Panamá: Panamá Pr./ Cerro Campana, 850m./ $8^{\circ} 40^{\prime} \mathrm{N}, 79^{\circ} 56^{\prime} \mathrm{W} / 13$ May 73 Stockwell”, "HOLOTYPE/ Floromadanel tumens/ Prena, 2009” (CMNC).

Paratypes: 2 males. PANAMA: Panamá Prov., Cerro Campana, 26.6.1971, H. A. Hespenheide (HPSC), ditto, 16.7.1976, W. Clark (USNM). 


\section{Description:}

Total length 4.8-6.5 mm, standard length 4.6-6.1 mm, width 2.7-3.7 mm; integument dark brown, ochre scales in incomplete dorsolateral and median pronotal vittae and in irregular clusters particularly on apical half of elytra (Fig. 5-6); pronotum gibbous, disk distinctly arched in lateral view, punctures confluent, intervals granular, confluent in midline; scutellum square, apex round to acuminate; elytra subtriangular, conjointly rounded and completely covering pygidium, interstriae costate except for flat portions of disk; ventral tooth variously reduced on profemur, largest on mesofemur; tibiae with praemucro indistinct, male with sparse fringe of long hairs on ventral edge of protibia; claws subconnate at base; male genitalia similar to those of F. atrorubens.

\section{Plant association:}

Unknown.

\section{Distribution:}

The species is known only from Cerro Campana in central Panama.

\section{Epithet:}

A Latin present participle derived from tumeo meaning "swollen".

\section{References}

Casey, T. L. 1922: Studies in the rhynchophorous subfamily Barinae of the Brazilian fauna. - Memoirs on the Coleoptera 10: 1-520.

Champion, G. C. 1907: Biologia Centrali-Americana. Insecta. - Coleoptera IV.5 (part): pp. 137-240.

Hustache, A. 1938: Pars 163; Curculionidae, Barinae. - In: W. Junk \& S. Schenkling: Coleopterorum catalogus. Verlag für Naturwissenschaften, 's-Gravenhage: 219 pp.

LACORDAIRE, T. 1863: Histoire naturelle des insectes. - Genera des coléoptères ou exposé méthodique et critique de tous les genres proposés jusqu'ici dans cet ordre d'insectes, Vol. 6. Roret, Paris: 637 pp.

LACORDAire, T. 1866: Histoire naturelle des insectes. - Genera des coléoptères ou exposé méthodique et critique de tous les genres proposés jusqu'ici dans cet ordre d'insectes, Vol. 7. Roret, Paris: 620 pp.

Lyal, C. H. C.; Douglas, D. A. \& Hine, S. J. 2006: Morphology and systematic significance of sclerolepidia in the weevils (Coleoptera: Curculionoidea). - Systematics and Biodiversity 4: 203-241.

Prena, J. 2003: The Pardisomus species from Costa Rica, with descriptions of four new species and one larva (Coleoptera, Curculionidae, Baridinae). - Beiträge zur Entomologie 53: 199-216.

SchönherR, C. J. 1933: Tabula synoptica familiae curculionidum. - In: Synonymia insectorum. Genera et species curculionidum, Vol. 1 (1). Roret, Paris: 1-27.

SCHÖNHERR, C. J. 1945: Synopsis geographica familae curculionidum. - In: Synonymia insectorum. Genera et species curculionidum, Vol. 8 (2). Roret, Paris; Fleischer, Lipsia: 341.1-341.27.

\section{Author's address:}

Jens Prena

Systematic Entomology Laboratory

clo National Museum of Natural History

Washington, D.C. 20013-7012

U.S.A.

e-mail: jens.prena@ars.usda.gov

\section{Subject editor:}

Dr. L. ZerChe 